\title{
A taxonomic review of the genus Microbispora and a proposal to transfer two species to the genus Actinomadura and to combine ten species into Microbispora rosea
}

\author{
Shinji Miyadoh, ${ }^{*}$ Shoichi Amano, Hiroyoshi Tohyama and TaKashi Shomura \\ Pharmaceutical Research Center, Meiji Seika Kaisha Ltd, Morooka, Kohoku-ku, Yokohama, 222 Japan
}

(Received 2 October 1989; revised 25 April 1990; accepted 4 May 1990)

\begin{abstract}
We conducted a taxonomic review of the genus Microbispora using chemotaxonomic and DNA-DNA hybridization techniques, and reached the following conclusions: Microbispora viridis should be transferred to the genus Actinomadura as Actinomadura rugatobispora comb. nov., nom. nov. (type strain SF2240 = IFO 14382 = JCM 3366) and Microbispora echinospora should be transferred to the genus Actinomadura as Actinomadura echinospora comb. nov. (type strain JCM $3148=$ ATCC 27300). We also propose that Microbispora rosea, Microbispora amethystogenes, Microbispora chromogenes, Microbispora diastatica, Microbispora indica, Microbispora karnatakensis and Microbispora parva should be combined into the species Microbispora rosea subsp. rosea (type strain JCM 3006 $=$ ATCC 12950), and that Microbispora aerata, Microbispora thermodiastatica and Microbispora thermorosea should be combined and transferred to the new subspecies Microbispora rosea subsp. aerata comb. nov. (type strain IFO $12581=$ ATCC 15448). Microbispora bispora clearly differs from these ten strains at the species level.
\end{abstract}

\section{Introduction}

As originally described by Nonomura \& Ohara (1957), the genus Microbispora (type species $M$. rosea) of the order Actinomycetales is characterized by the formation of longitudinally paired spores on the aerial mycelium. In the same year, the genus Waksmania (type species $W$. rosea) was independently proposed by Lechevalier \& Lechevalier (1957). Henssen (1957) also described a new species, Thermopolyspora bispora $(=M$. bispora $)$. These two genera are now regarded as synonyms of Microbispora (Lechevalier, 1965). Nonomura \& Ohara $(1960,1969 a, b)$ isolated several new species from Japanese soils (M. amethystogenes, $M$. chromogenes, $M$. diastatica, $M$. parva, $M$. thermodiastatica and $M$. thermorosea) by developing the dry heat method. Gerber \& Lechevalier (1964) created a new species, $M$. aerata, to accommodate the producers of phenazines and phenoxazinones. Subsequently, Nonomura \& Ohara (1971) proposed the name $M$. echinospora for organisms forming spiny ornamented spores. These authors stated that the spore-bearing characteristics of the species resembled those of the genus Actinomadura. In 1985, we reported a new taxon, $M$. viridis, for organisms bearing rugose ornamented spores and having a green aerial mycelium (Miyadoh et al., 1985). Rao et al. (1987) isolated two new species, $M$. karnatakensis and $M$. indica, from Indian soils. There are now 13 valid species in the genus Microbispora.

Several groups (Fischer et al., 1983; Athalye et al., 1985; Fowler et al., 1985; Poschner et al., 1985) have recently recognized that sporoactinomycetes with wall chemotype IIIB (a cell wall having meso-diaminopimelic acid as its major constituent and whole-cell hydrolysates containing madurose as a diagnostic sugar), such as the genera Actinomadura, Microbispora and Microtetraspora, could be divided into two aggregate groups using chemotaxonomic, molecular genetic and numerical phenetic methods. Goodfellow et al. (1988) proposed, unofficially, a new genus Nonomuria and recommended the transfer of the Actinomadura pusilla group to the new taxon. In 1989, we stated that the genus Microtetraspora (with the exception of Microtetraspora viridis and 'Microtetraspora caesia') and the Actinomadura pusilla group should be classified in a single genus (Miyadoh et al., 1989). Goodfellow (1989), in his introduction to the Maduromycetes in Bergey's Manual of Systematic Bacteriology, vol. 4, took account of these more recent findings in recommending that the genus Actinomadura be restricted to Actinomadura madurae and related 
species (A. madurae group) and that Actinomadura pusilla and related taxa (A. pusilla group) merited separate generic status.

Between the publication of Bergey's Manual of Determinative Bacteriology, (8th edn) in 1974 and Bergey's Manual of Systematic Bacteriology, vol. 4 in 1989 , the suprageneric and generic classification of actinomycetes has been revolutionized by chemical and genetic methods, especially ribosomal RNA sequencing analysis. Nonetheless, species-level classification remains equivocal in several genera. In this paper, we will conduct a taxonomic review of the genus Microbispora, using results from chemotaxonomic and DNA-DNA hybridization techniques to clarify the speciation of the genus.

\section{Methods}

Bacterial strains. Strains SF2240 and SF2292 were isolated by the dry heat method (Nonomura \& Ohara, 1969a) from soil samples collected at Takayama, Gifu Prefecture, and Wakayama, Wakayama Prefecture, Japan, respectively. The type strains used in this study are listed in Table 1. These strains were obtained from the Japan Collection of Micro-organisms (JCM), Saitama, Japan; the Institute for Fermentation (IFO), Osaka, Japan; and the American Type Culture Collection (ATCC), Rockville, Md, USA.

Morphological, cultural and physiological characteristics. The general methods of taxonomic characterization have been described previously (Miyadoh et al., 1987, 1989). For scanning electron microscopy, a spore-bearing agar block was fixed in osmium tetroxide fumes overnight, frozen in liquid nitrogen, and then freeze-dried. Each specimen was coated with gold-palladium by using an ion sputter

Table 1. Strains used in this study

\begin{tabular}{ll}
\hline \multicolumn{1}{c}{ Species } & Strain designation \\
\hline Actinomadura citrea & ATCC 27887 \\
Actinomadura malachitica & JCM 3297 \\
Actinomadura verrucosospora & JCM 3147 \\
Actinomadura pusilla & ATCC 27296 \\
Actinomadura ferruginea & JCM 3283 \\
Microbispora aerata & IFO 12581 \\
Microbispora amethystogenes & JCM 3021 \\
Microbispora bispora & ATCC 19993 \\
Microbispora bispora & JCM 3082* \\
Microbispora chromogenes & JCM 3022 \\
Microbispora diastatica & JCM 3023 \\
Microbispora echinospora & JCM 3148 \\
Microbispora indica & ATCC 35926 \\
Microbispora karnatakensis & ATCC 35927 \\
Microbispora parva & JCM 3024 \\
Microbispora rosea & JCM 3006 \\
Microbispora thermodiastatica & IFO 14046 \\
Microbispora thermorosea & IFO 14047 \\
Microbispora viridis & SF2240 (IFO 14328) \\
Microbispora viridis & SF2292* (IFO 14697) \\
\hline \hline
\end{tabular}

* These two strains are the only ones studied that are not type strains. instrument and was then observed with an electron microscope (model JEM 100C-ASID; Japan Electron Optics Laboratory Co.). The temperature range for growth was observed on agar media consisting of $1 \%(\mathrm{w} / \mathrm{v})$ starch, $0 \cdot 2 \%$ yeast extract and $2 \%(\mathrm{w} / \mathrm{v})$ agar, $\mathrm{pH} 7 \cdot 0$. Cells for chemical analysis were grown for $1-2 \mathrm{~d}$ in YD broth $[1 \%(\mathrm{w} / \mathrm{v})$ yeast extract, $1 \%(\mathrm{w} / \mathrm{v})$ glucose, $\mathrm{pH} 7.0$ ] on a rotary shaker $(220$ r.p.m.) at the temperature indicated below, harvested by centrifugation, and washed with distilled water. The cultivations were done at $55^{\circ} \mathrm{C}$ for M. bispora, $47^{\circ} \mathrm{C}$ and $37^{\circ} \mathrm{C}$ for $M$. aerata, M. thermodiastatica and $M$. thermorosea, and at $28^{\circ} \mathrm{C}$ for the remaining species.

Chemotaxonomic characterization. The methods used were similar to those described previously (Miyadoh et al., 1989). Briefly, isomers of diaminopimelic acid and sugars in purified cell wall and whole-cell hydrolysates were determined by the methods of Becker et al. (1965) and Lechevalier (1968). Phospholipids were analysed by the procedure of Lechevalier et al. (1981). Menaquinones were analysed using mass spectrometry and high-performance liquid chromatography (Tamaoka et al., 1983). The compositions of methyl-esterified cellular fatty acids were determined by gas chromatography with capillary columns. The $\mathrm{mol} \% \mathrm{G}+\mathrm{C}$ values of the DNAs were calculated from their thermal denaturation temperatures (Marmur et al., 1962) by using spectrophotometry in $0.1 \times \mathrm{SSC}(1 \times \mathrm{SSC}$ is $0.15 \mathrm{M}-\mathrm{NaCl}$ plus $0.015 \mathrm{M}$-sodium citrate, $\mathrm{pH} 7 \cdot 0$ ).

DNA-DNA hybridization. The DNA isolation procedure and the method of DNA-DNA hybridization were as descrited previously (Miyadoh et al., 1989). The pelleted wet cells were frozen, ground into fine powder under liquid nitrogen using a blender and suspended in TES ( $0.2 \mathrm{M}$-Tris/ $\mathrm{HCl}, 0.02 \mathrm{M}$-EDTA, $0.05 \mathrm{M}-\mathrm{NaCl}, \mathrm{pH} 8.0)$ containing $1 \%(\mathrm{w} / \mathrm{v})$ SDS at $40^{\circ} \mathrm{C}$. Total DNA was extracted with phenol, precipitated with ethanol, then spooled onto a glass rod. This total DNA was dissolved in $0.05 \times$ TES and then treated with ribonuclease and protease. DNA probes (100 ng purified DNA per labelling reaction) were radiolabelled with 20 to $30 \mu \mathrm{Ci}\left[\alpha^{-32} \mathrm{P}\right] \mathrm{dCTP}$ using a multiprime DNA labelling kit (Amersham). Hybridizations were done on nylon membranes (Amersham) according to the dot blotting protocol of the supplier. Unlabelled target DNAs $(0.6 \mu \mathrm{g})$ were spotted onto a membrane in triplicate, denatured with $1.5 \mathrm{M}-\mathrm{NaCl} / 0.5 \mathrm{M}-$ $\mathrm{NaOH}$, neutralized with $1.5 \mathrm{M}-\mathrm{NaCl} / 0.5 \mathrm{M}-\mathrm{Tris} / \mathrm{HCl} / 0.001 \mathrm{M}-\mathrm{EDTA}$, pH 7.5, and then fixed to the membrane using an ultraviolet transilluminator. The blotted membranes were prehybridized with 10 to $15 \mathrm{ml}$ of hybridization solution [ $3 \times \mathrm{SSC} / 0 \cdot 1 \%$ SDS containing denatured non-homologous DNA from calf thymus at a final concentration of $100 \mu \mathrm{g} \mathrm{ml}^{-1}$ and $4 \times$ Denhardt's solution $(0.02 \% \mathrm{BSA}$, $0.02 \%$ polyvinylpyrrolidone and $0.02 \%$ Ficoll)] in a plastic bag at $70{ }^{\circ} \mathrm{C}$ for 1 to $2 \mathrm{~h}$. Heat-denatured probe $(50 \mathrm{ng})$ was then added to the bag. The reassociation reaction between the membrane-fixed DNA and ${ }^{32} \mathrm{P}$-labelled DNA was done at $70^{\circ} \mathrm{C}$ for 16 to $20 \mathrm{~h}$. After hybridization, the membranes were washed once in $2 \times \mathrm{SSC} / 0.1 \% \mathrm{SDS}$ at $70^{\circ} \mathrm{C}$ for $1 \mathrm{~h}$. These membranes were air-dried, exposed to X-ray film at $-80^{\circ} \mathrm{C}$ overnight, then cut into individual dots in order to measure the radioactivity using a liquid scintillation counter. Hybridization experiments were repeated at least three times.

\section{Results}

\section{Taxonomic features of $M$. viridis and $M$. echinospora}

As shown in Tables 2 and 3 , the chemotaxonomic features of the two strains (SF2240 and SF2292) of $M$. viridis [wall chemotype IIIB, type PI phospholipid pattern (no nitrogenous phospholipids present), MK-9 
Table 2. Chemotaxonomic characteristics and growth temperature requirements of strains of Microbispora species

All strains had wall chemotype IIIB; cell walls having meso-diaminopimelic acid as a major constituent and whole-cell hydrolysates containing madurose as a diagnostic sugar.

\begin{tabular}{|c|c|c|c|c|c|c|c|c|c|c|c|c|}
\hline \multirow[b]{3}{*}{ Strain } & & \multicolumn{7}{|c|}{ Chemotaxonomic marker } & & & & \\
\hline & & \multirow{2}{*}{$\begin{array}{l}\mathrm{Mol} \% \\
\mathrm{G}+\mathrm{C}\end{array}$} & \multirow[b]{2}{*}{ Phospholipid* } & \multicolumn{5}{|c|}{ Menaquinone $\dagger$, MK-9\% } & \multicolumn{4}{|c|}{ Growth at: } \\
\hline & & & & $\left(\mathrm{H}_{0}\right)$ & $\left(\mathrm{H}_{2}\right)$ & $\left(\mathrm{H}_{4}\right)$ & $\left(\mathbf{H}_{6}\right)$ & $\left(\mathrm{H}_{8}\right)$ & $25^{\circ} \mathrm{C}$ & $35^{\circ} \mathrm{C}$ & $55^{\circ} \mathrm{C}$ & $60^{\circ} \mathrm{C}$ \\
\hline M. rosea & JCM 3006 & 71 & PIV & 21 & 49 & 30 & & & + & + & - & - \\
\hline M. amethystogenes & JCM 3021 & 71 & PIV & 21 & 54 & 21 & 2 & & + & + & - & - \\
\hline M. chromogenes & JCM 3022 & 71 & PIV & 11 & 34 & 50 & 3 & & + & + & - & - \\
\hline M. diastatica & JCM 3023 & 71 & PIV & 26 & 51 & 23 & & & + & + & - & - \\
\hline$M$. indica & ATCC 35926 & 71 & PIV & 15 & 43 & 40 & 1 & & + & + & - & - \\
\hline M. karnatakensis & ATCC 35927 & 71 & PIV & 15 & 32 & 46 & 5 & & + & + & - & - \\
\hline$M$. parva & JCM 3024 & 71 & PIV & 42 & 45 & 12 & & & + & + & - & - \\
\hline \multirow[t]{2}{*}{ M. aerata } & IFO 12581 & 72 & PIV & 52 & 36 & 9 & & & - & + & + & - \\
\hline & & & & 40 & 36 & 20 & 2 & & & & & \\
\hline \multirow[t]{2}{*}{ M. thermodiastatica } & IFO 14046 & 72 & PIV & 8 & 44 & 43 & 3 & & - & + & + & - \\
\hline & & & & 9 & 33 & 47 & 9 & & & & & \\
\hline \multirow[t]{2}{*}{ M. thermorosea } & IFO 14047 & 72 & PIV & 2 & 14 & 57 & 22 & & - & + & + & - \\
\hline & & & & 5 & 20 & 51 & 20 & & & & & \\
\hline M. bispora & ATCC 19993 & 71 & PIV $^{a}$ & 75 & 19 & 4 & & & - & - & + & + \\
\hline M. bispora & JCM 3082 & 71 & PIV $^{a}$ & 55 & 32 & 11 & 2 & & - & - & + & + \\
\hline M. viridis & SF2240 & 73 & $\mathrm{PI}^{b}$ & & & 1 & 64 & 35 & + & + & - & - \\
\hline M. viridis & SF2292 & 73 & PI & & & 11 & 73 & 15 & + & + & - & - \\
\hline M. echinospora & JCM 3148 & 74 & PI & & & 1 & 97 & 2 & + & + & - & - \\
\hline
\end{tabular}

* Type PI phospholipid, no nitrogenous phospholipids present; type PIV phospholipid, glucosamine-containing phospholipids present. ${ }^{a} \mathrm{While}$ the strains of genus Microbispora with type PIV phospholipid pattern contained large quantities of glucosamine-containing phospholipids, the two strains of $M$. bispora contained only small amounts. All of the strains with type PIV phospholipid contained phosphatidylethanolamine, but none contained phosphatidylglycerol. ' In a previous paper (Miyadoh et al., 1985), we described incorrectly that $M$. viridis SF2240 had a type PIV phospholipid pattern.

$\dagger$ MK-9 $\left(\mathrm{H}_{2}\right)$, menaquinones having two of the nine isoprene units hydrogenated. No mycolic acids were formed by any strains. Menaquinones of $M$. aerata, $M$. thermodiastatica and $M$. thermorosea were analysed at the two cultivation conditions of $37^{\circ} \mathrm{C}$ for $2 \mathrm{~d}$ (upper line) and $47^{\circ} \mathrm{C}$ for $1 \mathrm{~d}($ lower line).

$\left(\mathrm{H}_{6}\right)$ (hexahydrogenated menaquinones with nine isoprene units) as the predominant menaquinone, 16:0 (palmitic acid), 18:1 (oleic acid) and 10Me-18 (tuberculostearic acid) as the major fatty acids, and $73 \mathrm{~mol} \% \mathrm{G}+\mathrm{C}]$ were identical to those of the A. madurae group (i.e. $A$. citrea ATCC 27887 and A. verrucosospora JCM 3147) (Goodfellow, 1989), and were clearly different from those of typical Microbispora species. Also, on the basis of the DNA-DNA hybridization data shown in Table 4, these two strains were more closely related to strains of the $A$. madurae group (homology value 18 to $22 \%$; mean $19.5 \%$ ) than to the other Microbispora strains (homology value 4 to $12 \%$; mean $7.1 \%$ ).

The chemotaxonomic features of $M$. echinospora JCM 3148 are summarized as follows: wall chemotype IIIB, type PI phospholipid pattern, $\mathrm{MK}-9\left(\mathrm{H}_{6}\right)$ as predominant menaquinone, 17:0, iso-18, 10Me-17 and $10 \mathrm{Me}-18$ as the major fatty acids, and $74 \mathrm{~mol} \% \mathrm{G}+\mathrm{C}$. These features showed a close similarity to $A$. madurae group strains (ATCC 27887 and JCM 3147) and to M. viridis strains (SF2240 and SF2292). The fatty acid profile of $M$. echinospora JCM 3148 (Table 3) was considered to be intermediate between Actinomadura and Microbispora, and the DNA homology values indicated a moderately close relationship to strains of the $A$. madurae group and $M$. viridis (homology value 13 to $15 \%$; mean $14.0 \%$ ).

\section{Taxonomic features of the other Microbispora species}

As shown in Table 2, the other species of the genus Microbispora can be separated into two groups according to their temperature range for growth, either mesophilic or thermophilic (growth at $55^{\circ} \mathrm{C}$ ). Mesophilic strains, $M$. rosea JCM 3006, M. amethystogenes JCM 3021, $M$. chromogenes JCM 3022, $M$. diastatica JCM 3023, $M$. indica ATCC 35926, M. karnatakensis ATCC 35927 and $M$. parva JCM 3024, were closely related to each other on the basis of DNA homology (homology value 48 to $93 \%$; mean $64.7 \%$ ) and also in their chemotaxonomy [wall chemotype IIIB, type PIV phospholipid pattern (glucosamine-containing phospholipids present), MK-9 $\left(\mathrm{H}_{0}\right)$, MK-9 $\left(\mathrm{H}_{2}\right)$ and MK-9 $\left(\mathrm{H}_{4}\right)$ as the predominant 
Table 3. Fatty acid composition of the test strains

Abbreviations for fatty acids are illustrated by the following examples: straight-chain saturated - hexadecanoic acid (palmitic acid, $16: 0$ ); isobranched - 14-methylpentadecanoic acid (i-16); anteiso-branched - 14-methylhexadecanoic acid (a-17); 10-methyl-branched-10-methyloctadecanoic acid (tuberculostearic acid, $10 \mathrm{Me}-18$ ); monounsaturated - octadecenoic acid (oleic acid, $18: 1$ ). Fatty acids of $M$. aerata, M. thermodiastatica and $M$. thermorosea were analysed at the two cultivation conditions of $37^{\circ} \mathrm{C}$ for $2 \mathrm{~d}$ (upper line) and $47^{\circ} \mathrm{C}$ for $1 \mathrm{~d}$ (lower line).

\begin{tabular}{|c|c|c|c|c|c|c|c|c|c|c|c|c|c|c|}
\hline \multirow[b]{3}{*}{ Strain } & & \multicolumn{13}{|c|}{ Fatty acid composition $(\%)$} \\
\hline & & \multicolumn{4}{|c|}{ Straight chain } & \multicolumn{4}{|c|}{ Branched chain } & \multicolumn{3}{|c|}{ 10-Methyl-branched chain } & \multicolumn{2}{|c|}{ Unsaturated } \\
\hline & & $15: 0$ & $16: 0$ & $17: 0$ & $18: 0$ & $\mathrm{i}-15$ & $\mathrm{i}-16$ & $\mathrm{i}-18$ & $a-17$ & $10 \mathrm{Me}-16$ & $10 \mathrm{Me}-17$ & $10 \mathrm{Me}-18$ & $16: 1$ & $18: 1$ \\
\hline M. rosea & JCM 3006 & 2 & 9 & 10 & 3 & 2 & 43 & & 9 & 2 & 12 & 1 & 3 & 3 \\
\hline M. amethystogenes & JCM 3021 & 4 & 10 & 5 & 3 & 5 & 18 & & 14 & 7 & 15 & 6 & 7 & 5 \\
\hline M. chromogenes & JCM 3022 & 3 & 6 & 7 & 2 & 4 & 35 & 1 & 6 & 9 & 14 & 4 & 3 & 2 \\
\hline M. diastatica & JCM 3023 & 4 & 7 & 6 & 2 & 3 & 30 & & 10 & 9 & 17 & 3 & 5 & 1 \\
\hline$M$. indica & ATCC 35926 & 3 & 7 & 4 & 2 & 2 & 32 & & 11 & 8 & 13 & 3 & 5 & 5 \\
\hline M. karnatakensis & ATCC 35927 & 3 & 8 & 7 & 2 & 1 & 39 & 4 & 9 & 4 & 10 & 3 & 3 & 3 \\
\hline M. parva & JCM 3024 & 2 & 7 & 2 & 2 & 4 & 20 & & 4 & 16 & 15 & 8 & 4 & 5 \\
\hline \multirow[t]{2}{*}{ M. aerata } & IFO 12581 & 1 & 7 & 6 & 1 & & 42 & & 8 & 5 & 16 & 5 & & \\
\hline & & 7 & 7 & 16 & 2 & 2 & 38 & 3 & 6 & 1 & 6 & 2 & & \\
\hline \multirow[t]{2}{*}{ M. thermodiastatica } & IFO 14046 & & 7 & 2 & 2 & 1 & 32 & 3 & 21 & 5 & 9 & 6 & & \\
\hline & & 1 & 8 & 7 & 3 & 1 & 45 & 7 & 10 & 1 & 4 & 2 & 1 & 1 \\
\hline \multirow[t]{2}{*}{ M. thermorosea } & IFO 14047 & & 7 & 1 & 2 & & 32 & 3 & 25 & 5 & 9 & 6 & & \\
\hline & & 1 & 9 & 9 & 3 & 2 & 23 & 8 & 21 & 1 & 3 & 4 & 1 & 1 \\
\hline M. bispora & ATCC 19993 & 1 & 6 & 2 & 3 & & 55 & 6 & 8 & & 4 & 3 & 2 & 8 \\
\hline M. bispora & JCM 3082 & 1 & 6 & 3 & 3 & & 54 & 7 & 8 & 2 & 3 & 3 & 2 & 6 \\
\hline A. pusilla & ATCC 27296 & 5 & 4 & 4 & 1 & 4 & 21 & & 10 & 2 & 24 & 4 & 3 & 4 \\
\hline A. ferruginea & JCM 3283 & 2 & 4 & 8 & 1 & 1 & 18 & 7 & 22 & 1 & 17 & 5 & 3 & 2 \\
\hline M. viridis & SF2240 & & 28 & & 11 & & 5 & & & & & 18 & 9 & 27 \\
\hline M. viridis & SF2292 & & 28 & & 6 & & 5 & & & & & 23 & 10 & 27 \\
\hline M. malachitica & JCM 3297 & & 24 & 2 & 7 & & 8 & & 1 & & 1 & 20 & 5 & 29 \\
\hline M. verrucosospora & JCM 3147 & & 35 & 1 & 7 & & 3 & & & 1 & & 24 & 5 & 22 \\
\hline M. citrea & ATCC 27887 & & 34 & 2 & 6 & & 3 & & 1 & 1 & 1 & 22 & 4 & 22 \\
\hline M. echinospora & JCM 3148 & 5 & 10 & 22 & 7 & & 18 & 7 & 2 & 1 & 13 & 13 & & \\
\hline
\end{tabular}

Table 4. DNA homologies of strains of Microbispora and related strains

\begin{tabular}{|c|c|c|c|c|c|c|c|c|c|c|c|c|c|c|c|}
\hline \multirow{2}{*}{\multicolumn{2}{|c|}{ Source of unlabelled DNA }} & \multicolumn{14}{|c|}{ Percentage hybridization with ${ }^{32} \mathrm{P}$-labelled DNA from: } \\
\hline & & $\begin{array}{l}\text { JCM } \\
3006\end{array}$ & $\begin{array}{l}\text { JCM } \\
3021\end{array}$ & $\begin{array}{l}\text { JCM } \\
3022\end{array}$ & $\begin{array}{l}\text { JCM } \\
3023\end{array}$ & $\begin{array}{c}\text { ATCC } \\
35926\end{array}$ & $\begin{array}{c}\text { ATCC } \\
35927\end{array}$ & $\begin{array}{l}\text { JCM } \\
3024\end{array}$ & $\begin{array}{c}\text { IFO } \\
12581\end{array}$ & $\begin{array}{c}\text { IFO } \\
14046\end{array}$ & $\begin{array}{c}\text { IFO } \\
14047\end{array}$ & $\begin{array}{c}\text { ATCC } \\
19993\end{array}$ & SF2240 & SF2292 & $\begin{array}{l}\text { JCM } \\
3148\end{array}$ \\
\hline M. rosea & JCM3006 & 100 & 48 & 61 & 51 & 88 & 69 & 62 & 38 & 42 & 41 & 15 & 6 & 5 & 8 \\
\hline M. amethystogenes & JCM 3021 & 57 & 100 & 64 & 64 & 60 & 56 & 54 & 44 & 51 & 48 & 14 & 9 & 6 & 11 \\
\hline M. chromogenes & JCM 3022 & 68 & 55 & 100 & 74 & 81 & 71 & 60 & 43 & 45 & 44 & 16 & 9 & 5 & 9 \\
\hline M. diastatica & JCM 3023 & 68 & 58 & 93 & 100 & 82 & 91 & 59 & 41 & 57 & 55 & 15 & 8 & 6 & 10 \\
\hline M. indica & ATCC 35926 & 83 & 48 & 68 & 54 & 100 & 55 & 61 & 40 & 38 & 37 & 16 & 7 & 5 & 9 \\
\hline M. karnatakensis & ATCC 35927 & 52 & 54 & 61 & 78 & 60 & 100 & 55 & 39 & 40 & 44 & 14 & 6 & 6 & 8 \\
\hline M. parva & JCM 3024 & 78 & 56 & 74 & 69 & 65 & 54 & 100 & 50 & 60 & 52 & 18 & 10 & 7 & 9 \\
\hline M. aerata & IFO 12581 & 45 & 47 & 54 & 53 & 51 & 51 & 57 & 100 & 94 & 68 & 18 & 7 & 6 & 10 \\
\hline M. thermodiastatica & IFO 14046 & 46 & 40 & 43 & 37 & 40 & 46 & 46 & 68 & 100 & 64 & 19 & 9 & 7 & 7 \\
\hline$M$. thermorosea & IFO 14047 & 52 & 48 & 48 & 42 & 43 & 45 & 47 & 59 & 80 & 100 & 17 & 8 & 6 & 8 \\
\hline M. bispora & ATCC 19993 & 14 & 16 & 17 & 18 & 15 & 15 & 18 & 18 & 22 & 20 & 100 & 6 & 5 & 6 \\
\hline M. bispora & JCM 3082 & 13 & 14 & 15 & 16 & 17 & 13 & 17 & 17 & 17 & 19 & 55 & 5 & 4 & 6 \\
\hline M. viridis & SF2240 & 7 & 12 & 8 & 8 & 9 & 8 & 10 & 8 & 10 & 8 & 6 & 100 & 85 & 14 \\
\hline M. viridis & SF2292 & 7 & 8 & 6 & 7 & 8 & 5 & 9 & 5 & 8 & 7 & 5 & 82 & 100 & 13 \\
\hline M. echinospora & JCM 3148 & 7 & 5 & 7 & 10 & 6 & 9 & 9 & 10 & 6 & 6 & 6 & 15 & 13 & 100 \\
\hline A. citrea & ATCC 27887 & 6 & 7 & 8 & 10 & 8 & 10 & 8 & 7 & 8 & 9 & 6 & 22 & 19 & 14 \\
\hline A. verrucosospora & JCM 3147 & 7 & 5 & 6 & 8 & 6 & 8 & 6 & 9 & 8 & 9 & 7 & 19 & 18 & 15 \\
\hline A. pusilla & ATCC 27296 & 15 & 16 & 14 & 16 & 13 & 16 & 13 & 15 & 14 & 13 & 12 & 8 & 6 & 8 \\
\hline A. ferruginea & JCM 3283 & 16 & 17 & 15 & 16 & 18 & 15 & 15 & 16 & 17 & 15 & 14 & 12 & 7 & 10 \\
\hline
\end{tabular}


menaquinones, iso- 16 and $10 \mathrm{Me}-17$ as the major fatty acids, and 71 to $72 \mathrm{~mol} \% \mathrm{G}+\mathrm{C}$ ]. These chemotaxonomic features were virtually the same as those of the $A$. pusilla group (Goodfellow, 1989). The three thermophilic strains, namely $M$. aerata IFO 12581 , $M$. thermodiastatica IFO 14046 and $M$. thermorosea IFO 14047, exhibited higher DNA homologies with one another (homology value 59 to $94 \%$; mean $72.2 \%$ ) than with the mesophilic strains (homology value 37 to $60 \%$; mean $46.0 \%$ ).

The two strains of $M$. bispora (ATCC 19993 and JCM 3082) clearly differed from these ten strains. Chemotaxonomically, the $M$. bispora strains had the following characteristics: MK-9 $\left(\mathrm{H}_{0}\right)$ as predominant menaquinone, with glucosamine-containing phospholipids and 10-methylfatty acids in low amounts. They were able to grow at $65^{\circ} \mathrm{C}$ but not at $35^{\circ} \mathrm{C}$.

\section{Discussion}

Eleven species of the genus Microbispora are characterized by smooth-surfaced spores (smooth spore species), as shown in Fig. $1(a, b)$. M. echinospora forms spinose spores (Fig. $1 c$ ) and $M$. viridis forms rugose spores (Fig. $1 d$ ). The aerial mycelia of $M$. echinospora and $M$. viridis differentiate into a non-sporogenous main axis with sporogenous side branches arising from the axis, whereas those of the smooth-spored species bear spores on a wide range of hyphae (Nonomura \& Ohara, 1971). The number of spores per chain in $M$. echinospora and $M$. viridis is sometimes three (mostly two); the smoothspored species never have three spores per chain. Recently, Nonomura (1989) reported that M.echinospora formed paired spores in clusters. As described above, $M$. echinospora and $M$. viridis are clearly distinguished from the smooth-spored species in morphology, despite their characteristic formation of paired spores on aerial hyphae. Chemotaxonomically (Table 2), the smoothspored species have a type PIV phospholipid pattern, with MK-9 $\left(\mathrm{H}_{0}\right)$, MK-9 $\left(\mathrm{H}_{2}\right)$ and MK-9 $\left(\mathrm{H}_{4}\right)$ as the predominant menaquinones, while the spinose- and rugose-spored species have a type PI phospholipid pattern, with MK-9 $\left(\mathrm{H}_{6}\right)$ as the major menaquinone.

In Bergey's Manual of Systematic Bacteriology, vol. 4 (Nonomura, 1989), the genus Microbispora was defined on the basis of a combination of morphology and the following chemical properties: cell walls contain $N$-acetylated muramic acid and major amounts of mesodiaminopimelic acid, but no characteristic sugars; whole-cell hydrolysates contain madurose; menaquinones are partially saturated, with $\mathrm{MK}-9\left(\mathrm{H}_{4}\right)$ as major isoprenologue; major phospholipids include phosphatidylcholine and unknown glucosamine-containing compounds, but no phosphatidylglycerol is present.

\section{Taxonomic status of $M$. viridis and $M$. echinospora}

The chemotaxonomic data of $M$. viridis are clearly different from those of the genus Microbispora mentioned above. Our results indicate that $M$. viridis should be classified as a member of the $A$. madurae group. In the genus Actinomadura, there are no previously described species with the same morphology (greenish aerial masses and longitudinally paired spores having rugose surfaces with vertical ridges) as strains SF2240 and SF2292. Accordingly, we propose the transfer of Microbispora viridis Miyadoh et al. to the genus Actinomadura Lechevalier and Lechevalier (1970) as Actinomadura rugatobispora (ru.ga.to.bi'spo.ra. L. adj. rugato wrinkled; Gr. adj. bi paired; Gr. n. spora a spore; rugatobispora wrinkled paired-spores, referring to spore morphology) comb. nov., nom. nov. with strain SF2240 (= IFO 14328) as the type strain. In a previous paper (Miyadoh et al., 1989), we proposed the transfer of Microtetraspora viridis to the genus Actinomadura as $A$. viridis comb. nov. According to Rule 4la of the International Code of Nomenclature of Bacteria (1976, revision), authors are obliged to substitute a new specific epithet if the result of the combination would be a new homonym. Since this would be the case here, we have adopted A. rugatobispora as the new name.

Also, the chemical data of Microbispora echinospora indicate that it should be classified as a member of the A. madurae group, although it is not typical of that group. In the genus Actinomadura, there are no previously described species such as strain JCM 3148, which was characterized by a pinkish aerial mass and paired spores with a spinose surface. Therefore, we propose the transfer of Microbispora echinospora Nonomura and Ohara to the genus Actinomadura Lechevalier and Lechevalier as Actinomadura echinospora comb. nov., with strain JCM 3148 (= ATCC 27300) as the type strain. Goodfellow \& Pirouz (1982) found using numerical classification that three strains of Microbispora were recovered in a well-defined cluster, whereas $M$. echinospora and $M$. thermodiastatica showed little affinity to one another or to the $M$. rosea cluster. Poschner et al. (1985) reported that M. echinospora was more closely associated with the $A$. madurae group than with members of the genus Microbispora. With the exception of $M$. thermodiastatica, our studies reconfirmed these results.

With the transfer of $M$. viridis and $M$. echinospora, Actinomadura becomes a diverse genus both in sporechain morphology [ranging from the paired spores shown 

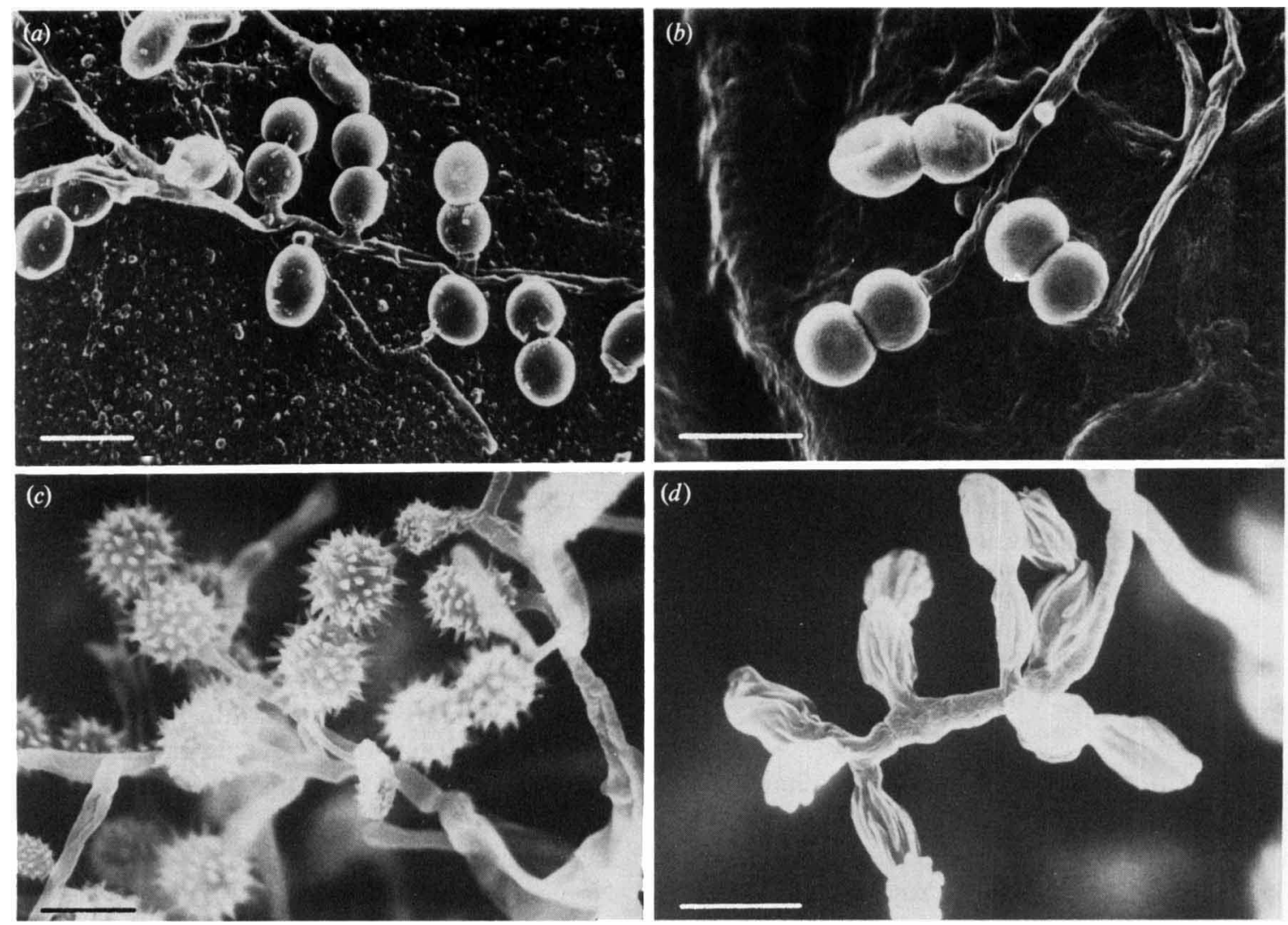

Fig. 1. Scanning electron micrographs of type strains of Microbispora species. (a) M. rosea JCM 3006, (b) M. aerata IFO 12581, (c) M. echinospora JCM 3148, (d) M. viridis SF2240. Bars, $2 \mu \mathrm{m}$.

in these species to the long spore chains observed in A. kijaniata (Horan \& Brodsky, 1982)] and in sporesurface morphology (smooth, warty, spinose and rugose). Other taxonomic properties of these strains are summarized in Table 5. On the other hand, as a result of the transfer of the two species, the genus Microbispora becomes a homogeneous and well-defined taxon in morphology (smooth paired-spore species) and in chemotaxonomy.

\section{Relationships among smooth-spored species of the genus} Microbispora

It is remarkable that ten type strains of smooth-spored species showed high homology values (mean $56.5 \%$ ) in every combination of probes and targets (Table 4, Fig. 2 ), whilst exhibiting very low homology (mean $16.4 \%$ ) with two strains of $M$. bispora, which also has smooth spores. These results lead us to the conclusion that smooth-spored species of Microbispora, with the exception of $M$. bispora, are so closely related to one another that they should be united into one species. The homology values between the thermophiles and the mesophiles described above are believed to differ at the subspecies level.

In Bergey's Manual of Systematic Bacteriology, Johnson (1984) states that DNA homology values in the range of 60 to $70 \%$ would appear to be a transitional point for delineating species. According to this guideline, the homology values among these ten species are relatively low for them to be regarded as synonyms. However, we believe that the clear discontinuity in the two mean values $(56.5 \%$ and $16.4 \%$ ) for DNA homology must represent a classificatory point at the species level. Accordingly, we propose that Microbispora rosea Nonomura and Ohara, Microbispora amethystogenes Nonomura and Ohara, Microbispora chromogenes Nonomura and Ohara, Microbispora diastatica Nonomura and Ohara, Microbispora indica Rao et al., 


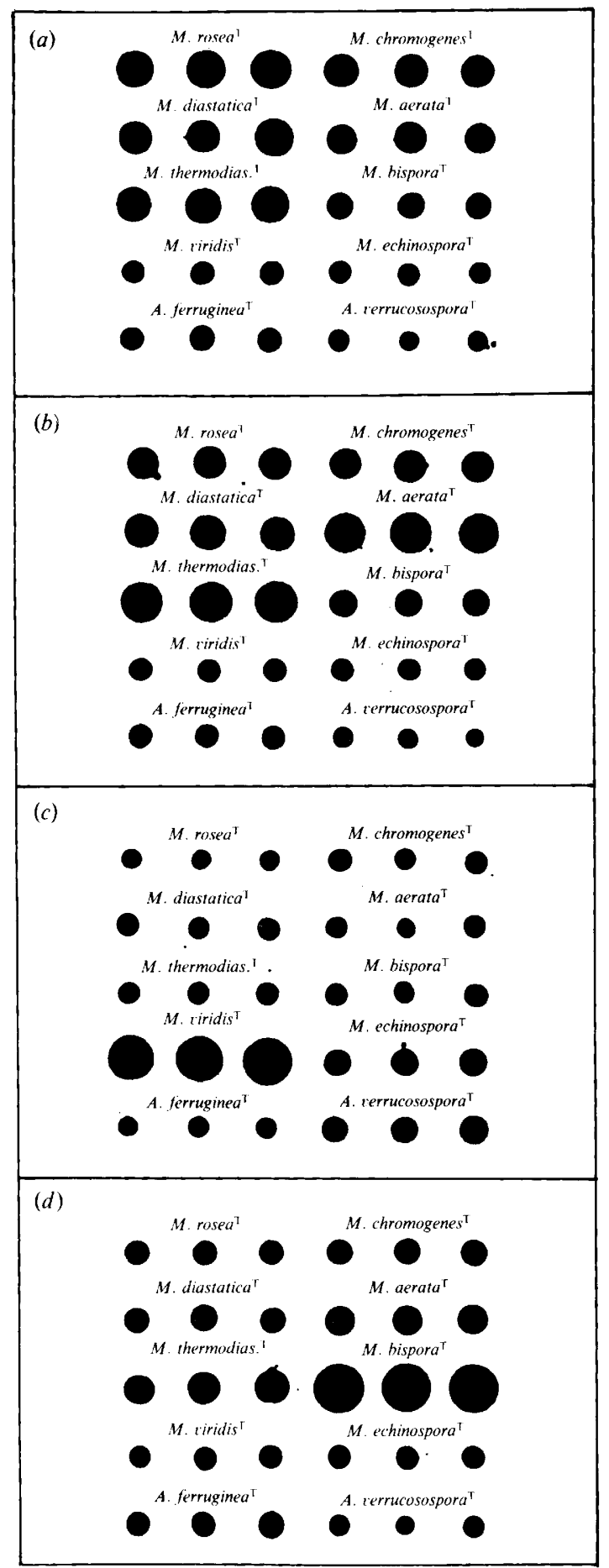

Fig. 2. Typical autoradiography of DNA-DNA dot hybridization of type strains of genus Microbispora. Target DNAs were spotted in triplicate in the following order: $M$. rosea JCM 3006, $M$. chromogenes JCM 3022, $M$. diastatica JCM 3023, $M$. aerata IFO 12581, $M$. thermodiastatica IFO 14046, M. bispora ATCC 19993, M. viridis SF2240, $M$. echinospora JCM 3148, A. ferruginea JCM 3282 and $A$. verrucosospora JCM 3147. The sources of ${ }^{32} \mathrm{P}$-labelled DNA used were $M$. rosea JCM $3006(a)$, M. aerata IFO $12581(b)$, M. viridis SF2240 (c) and M. bispora ATCC 19993 (d).
Microbispora karnatakensis Rao et al. and Microbispora parva Nonomura and Ohara are combined into the species Microbispora rosea subsp. rosea, with JCM 3006 (= ATCC 12950) as the type strain, and that Microbispora aerata Graber and Lechevalier, Microbispora thermodiastatica Nonomura and Ohara and Microbispora thermorosea Nonomura and Ohara should be combined and transferred to the new subspecies Microbispora rosea subsp. aerata comb. nov., with IFO 12581 (= ATCC 15448) as the type strain.

Microbispora species with smooth spores have generally been distinguished mainly by growth temperature requirements and a few physiological tests. In reference to the classification of the genus Microbispora, Williams \& Wellington (1981) stated that the validity of separating some species on the basis of one or two characteristics is questionable. Goodfellow \& Cross (1984) agreed with this comment. The physiological characteristics of $M$. rosea, $M$. amethystogenes, $M$. chromogenes, $M$. diastatica, $M$. parva, $M$. aerata, $M$. thermodiastatica and $M$. thermorosea are similar (Nonomura, 1989), and the differences among these species, such as iodinin production, starch hydrolysis and nitrate reduction, are believed to occur at the strain and not the species level. The emended species $M$. rosea is characterized by its morphology, pinkish aerial mass and requirement for B vitamins (particularly thiamin) for growth (Nonomura \& Ohara, 1957). As indicated in Table 2, growth temperature requirements were shown to be a diagnostic criterion for species and subspecies identification within the genus Microbispora. The menaquinone compositions of these ten strains showed variation in hydrogenation, but we decided that these variations could be accounted for by the versatility of the species. Also, the menaquinone compositions (Table 2) of $M$. aerata, $M$. thermodiastatica and $M$. thermorosea were not significantly affected by cultivation conditions (incubation at $37^{\circ} \mathrm{C}$ for $2 \mathrm{~d}$ and $47^{\circ} \mathrm{C}$ for $1 \mathrm{~d}$ ), whereas their fatty acid compositions (Table 3 ) changed partially, for example the amount of 10-methylfatty acids decreased during growth at the higher temperature.

$M$. bispora is distinguished from emended $M$. rosea by its growth temperature requirement and whitish aerial mass. Greiner-Mai et al. (1987), who studied the morphology and biochemistry of thermophilic actinomycetes, reported that $M$. bispora showed some physiological differences from $M$. aerata and $M$. thermodiastatica (for example, a striking resistance toward lysozyme). Poschner et al. (1985), who did DNA-DNA reassociation studies, reported that $M$. chromogenes showed distinctly high homologies with $M$. amethystogenes, $M$. thermodiastatica and $M$. aerata, whilst $M$. chromogenes and $M$. bispora shared a low homology. These results are consistent with our data. 
Table 5. Taxonomic characteristics of some strains of Microbispora

\begin{tabular}{|c|c|c|c|c|}
\hline Test & $\begin{array}{l}\text { M. viridis } \\
\text { SF2240 }\end{array}$ & $\begin{array}{l}\text { M. viridis } \\
\text { SF2292 }\end{array}$ & $\begin{array}{l}\text { M. echinospora } \\
\text { JCM } 3148\end{array}$ & $\begin{array}{c}\text { M. rosea } \\
\text { JCM } 3006\end{array}$ \\
\hline No. of spores per chain* & $2(1,3)$ & $2(1,3)$ & $2(1,3)$ & $2(1)$ \\
\hline Spore-bearing hyphae & Differentiated & Differentiated & Differentiated & Non-differentiated \\
\hline Spore surface & Rugose & Rugose & Spinose & Smooth \\
\hline Aerial mass colour $\dagger$ & Green (24ge) & Green (24ge) & Pink (5ca) & Pink (6ca) \\
\hline Liquefaction of gelatin & + & + & + & - \\
\hline Hydrolysis of starch & + & + & - & - \\
\hline Reduction of nitrate & - & + & - & + \\
\hline Peptonization of milk & + & + & + & - \\
\hline Coagulation of milk & - & - & - & - \\
\hline B vitamin requirement & - & - & + & + \\
\hline Formation of melanoid pigment & - & - & - & - \\
\hline \multicolumn{5}{|l|}{ Utilization of : } \\
\hline D-Glucose & + & + & + & + \\
\hline Glycerol & + & + & $(+)$ & + \\
\hline D-Fructose & + & + & + & + \\
\hline D-Xylose & - & - & + & $(+)$ \\
\hline L-Arabinose & $(+)$ & - & + & + \\
\hline D-Mannitol & + & + & + & + \\
\hline myo-Inositol & - & - & - & - \\
\hline L-Rhamnose & + & + & - & + \\
\hline Raffinose & - & - & - & - \\
\hline Sucrose & $(+)$ & - & + & $(+)$ \\
\hline
\end{tabular}

+ , Positive; $(+)$, weakly positive; - , negative.

* The number of spores per chain is usually two (rarely one or three).

$\dagger$ The colour codes were taken from the Color Harmony Manual (Jacobson et al., 1958).

We are grateful to T. Hasegawa of the Institute for Fermentation, Osaka, Japan, and M. Hamada of the Institute of Microbial Chemistry, Tokyo, Japan, for their kind suggestions. We thank R. Sashida of Mitsubishi Kasei Corporation, Research Center, Yokohama, Japan, for her help with $\mathrm{mol} \% \mathrm{G}+\mathrm{C}$ analysis. We also thank L. Lockett for critically reviewing the manuscript.

\section{References}

Athalye, M., Goodfellow, M., Lacey, J. \& White, R. P. (1985). Numerical classification of Actinomadura and Nocardiopsis. International Journal of Systematic Bacteriology 35, 86-98.

BeCKer, B., LeCheValier, M. P. \& Lechevalier, H. (1965). Chemical composition of cell-wall preparations from strains of various formgenera of aerobic actinomycetes. Applied Microbiology 13, 236-243.

Fischer, A., Kroppenstedt, R. M. \& Stackebrandt, E. (1983). Molecular genetic and chemotaxonomic studies on Actinomadura and Nocardiopsis. Journal of General Microbiology 129, 3433-3446.

Fowler, V. J., LUDWIG, W. \& STACKebrandT, E. (1985). Ribonucleic acid cataloguing in bacterial systematics: the phylogeny of Actinomadura. In Chemical Methods in Bacterial Systematics, pp. 17-40. Edited by M. Goodfellow \& D. E. Minnikin. London: Academic Press.

Gerber, N. N. \& Lechevalier, M. P. (1964). Phenazines and phenoxazinones from Waksmania aerata sp. nov. and Pseudomonas iodina. Biochemistry 3, 598-602.

Goodfellow, M. (1989). Maduromycetes. In Bergey's Manual of Systematic Bacteriology, vol. 4, pp. 2509-2551. Edited by S. T. Williams \& J. G. Holt. Baltimore: Williams and Wilkins.
Goodfellow, M. \& Cross, T. (1984). Classification. In The Biology of the Actinomycetes, pp. 7-164. Edited by M. Goodfellow, M. Mordarski \& S. T. Williams. London: Academic Press.

Goodfellow, M. \& Pirouz, T. (1982). Numerical classification of sporoactinomycetes containing meso-diaminopimelic acid in the cell wall. Journal of General Microbiology 128, 503-527.

GoOdFEllow, M., STACKebRandT, E. \& KROPPENSTEDT, R. M. (1988), Chemotaxonomy and actinomycete systematics. In Biology of Actinomycetes '88, pp. 233-238. Edited by Y. Okami, T. Beppu \& H. Ogawara. Tokyo: Japan Scientific Societies Press.

Greiner-Mai, E., Kroppenstedt, R. M., KorN-Wendisch, F. \& KUTZNER, J. (1987). Morphological and biochemical characterization and emended descriptions of thermophilic actinomycete species. Systematic and Applied Microbiology 9, 97-109.

Henssen, A. (1957). Beitrage zur Morphologie und Systematik der thermophilen Actinomyceten. Archiv für Mikrobiologie 26, 374-414.

HoRAN, A. C. \& BRODSKY, B. C. (1982). A novel antibiotic-producing Actinomadura, Actinomadura kijaniata sp. nov. International Journal of Systematic Bacteriology 32, 195-200.

Jacobson, E., Grauville, W. C. \& Fogs, C. E. (1958). Color Harmony Manual, 4th edn. Chicago: Container Corporation of America.

JoHNSON, J. L. (1984). Nucleic acids in bacterial classification. In Bergey's Manual of Systematic Bacteriology, vol. 1, pp. 8-11. Edited by N. R. Krieg \& J. G. Holt. Baltimore: Williams and Wilkins.

LeCHEVAlier, H. A. (1965). Priority of the generic name Microbispora over Waksmania and Thermopolyspora. International Bulletin of Bacteriological Nomenclature and Taxonomy 15, 139-142.

LeChevalier, H. A. \& LecheValieR, M. P. (1970). A critical evaluation of the genera of aerobic actinomycetes. In The Actinomycetales, pp. 393-405. Edited by H. Prauser. Jena: Gustav Fisher Verlag.

LECHEVALIER, M. P. (1968). Identification of aerobic actinomycetes of clinical importance. Journal of Laboratory and Clinical Medicine 71, 934-944. 
Lechevalier, M. P. \& Lechevalier, H. (1957). A new genus of the Actinomycetales: Waksmania gen. nov. Journal of General Microbiology 17, 104-111.

Lechevalier, M. P., Stern, A. E. \& Lechevalier, H. A. (1981). Phospholipids in the taxonomy of actinomycetes. In Actinomycetes, pp. 111-116. Edited by P. Schaal \& G. Pulverer. Stuttgart: Gustav Fisher Verlag.

MARMUR, J. \& Doty, P. (1962). Determination of the base composition of deoxyribonucleic acid from its thermal denaturation temperature. Journal of Molecular Biology 5, 109-118.

Miyadoh, S., Tohyama, H., Amano, S., Shomura, T. \& Nind, T. (1985). Microbispora viridis, a new species of Actinomycetales. International Journal of Systematic Bacteriology 35, 281-284.

Miyadoh, S., Amano, S., Tohyama, H. \& Shomura, T. (1987) Actinomadura atramentaria, a new species of Actinomycetales. International Journal of Systematic Bacteriology 37, 342-346.

MiYadoH, S., ANZAI, H., Amano, S. \& Shomura, T. (1989). Actinomadura malachitica and Microtetraspora viridis are synonyms, and should be transferred as Actinomadura viridis comb. nov. International Journal of Systematic Bacteriology 39, 152-158.

Nonomura, H. (1989). The genus Microbispora Nonomura and Ohara 1957, 307AL. In Bergey's Manual of Systematic Bacteriology, vol. 4, pp. 2526-2531. Edited by S. T. Williams \& J. G. Holt. Baltimore: Williams and Wilkins.

Nonomura, H. \& OHaRa, Y. (1957). Distribution of actinomycetes in soil. II. Microbispora, a new genus of Streptomycetaceae. Journal of Fermentation Technology 35, 307-311.

Nonomura, H. \& OHARA, Y. (1960). Distribution of actinomycetes in soil. IV. The isolation and classification of the genus Microbispora. Journal of Fermentation Technology 38, 401-405.
NoNOMURA, H. \& OHARA, Y. (1969a). Distribution of actinomycetes in soil. VI. A culture method effective for both preferential isolation and enumeration of Microbispora and Streptosporangium strains in soil (part 1). Journal of Fermentation Technology 47, 463-469.

NonOMURA, H. \& OHARA, Y. (1969b). Distribution of actinomycetes in soil. VII. A cultural method effective for both preferential isolation and enumeration of Microbispora and Streptosporangium strains in soil (part 2). Classification of isolates. Journal of Fermentation Technology 47, 701-709.

Nonomura, H. \& OHARA, Y. (1971). Distribution of actinomycetes in soil. IX. New species of genera Microbispora and Microtetraspora, and their isolation method. Journal of Fermentation Technology 49, 887-894.

Poschner, J., Kroppenstedt, R. M., Fischer, A. \& Stackebrandt, E. (1985). DNA-DNA reassociation and chemotaxonomic studies on Actinomadura, Microbispora, Microtetraspora, Micropolyspora and Nocardiopsis. Systematic and Applied Microbiology 6, 264-270.

Rao, V. A., Prabhu, K. K., Sridhar, B. P., Venkateswarlu, A. \& ACTOR, P. (1987). Two new species of Microbispora from Indian soils: Microbispora karnatakensis sp. nov. and Microbispora indica $\mathrm{sp}$. nov. International Journal of Systematic Bacteriology 37, 181-185.

TAMAOKA, J., Katayama-Fujimura, Y. \& KuRAishi, H. (1983) Analysis of bacterial menaquinone mixtures by high performance liquid chromatography. Journal of Applied Bacteriology 54, 31-36.

Williams, S. T. \& Wellington, E. M. H. (1981). The genera Actinomadura, Actinopolyspora, Excellospora, Microbispora, Micropolyspora, Microtetraspora, Nocardiopsis, Saccharopolyspora and Pseudonocardia. In The Prokaryotes, vol. 2, pp. 2103-2117. Edited by M. P. Starr, H. Stolp, H. G. Truper, A. Balows \& H. G. Schlegel. Berlin: Springer-Verlag. 